\title{
171. 非対称フイルムの特性曲線の検討
}

\section{An Improvement of a Film Contrast by Using an Asymmetric System}

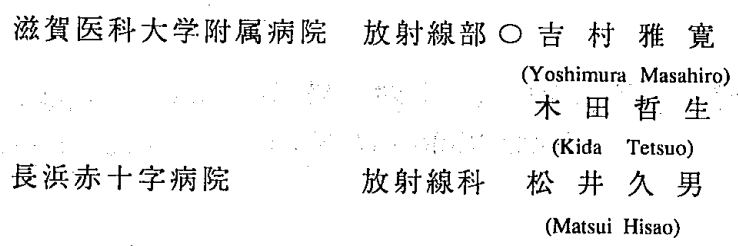

松 尾 悟
(Matsuo Satoru)
小 水 満
(Komizu Mitsuru)

(Matsui Hisao)

【目的】コダック社よりだされている非対称フィルムでの胸部写真はメーカー、ユーザーともさらに画質 改善の余地があると考えられる。その試みとして、我々は第 20 回秋季学術大会において非対称フイルムは フロント、バックの加算画像であることに着目し、特性曲線の形状についてシミュレーションし、評洒を行 った。さらに今回、バックの感度変化が胸部写真に与える影響について追加検討を行った。

【使用機器】東芝画像ファイリング装置（以下T D I S ）、画像出力装置:FUJIX LP-414、濃度計:コニカ PDM-65、ドラムスキャナデンシトメーター、ファントム: $5 \mathrm{~mm} \Phi 、 3 \mathrm{~mm}$ 厚アルミ(以下 $\mathrm{Al}$ ) $5 \mathrm{~mm} \Phi$ 、 $3 \mathrm{~mm}$ 厚アクリル (以下Ac)：増感紙フィルム系:KODAK HCシステム

【方法及び結果】関心領域をフイルムタイプ別に濃度測定をした結果をTab.1に示す。この結果より肺野 として1.7,縦隔として0.6の濃度で、 $5 \mathrm{~mm} \Phi 、 3 \mathrm{~mm}$ 厚のAl,Acを同一撮影条件でH Cシステムのフロント バックそれぞれ片面撮影を行った。そのオリジナルフィルムをT D I S でデジタル化し、階調シミュレーシ ヨンしたフロントと感度を変化させたバック 3 種類の特性曲線の処理を用いて加算画像を作成した。 そのシ ミュレーションした特性曲線及び相対感度を Fig.1 に示す。ただし、バックの特性曲線 B/nOは前回、高い評 価を得たガンマタイプ（以下GT）：O、ガンマアングル（以下GA）：0.7、ガンマシフト（以下GS）： 0.6 の゚ラメター処理を行っており、 $\mathrm{B} / \mathrm{nO}$ を標準とし、高感度の処理を $\mathrm{B} / \mathrm{hO}$ 、低感度の処理を $\mathrm{B} / \mathrm{lO}$ とした。 フロントの特性曲線F/ASは前回高い評価が得られたGT：A、GA：2.0、GS：0.7の処理をしたものである。 加算画像濃度0.6でのAcをFig.2に、1.7でのAl,Acのプロファイルを Fig.3に示す。0.6の濃度のAcではB/lOと する事でノイズが減少している。又、濃度1.7での信号は影著な差は無いが、バックをB/Oにすることでエ ッジが蚛調されており、鮮鋭度が改善されることが示唆でき、ノイズが減少している。そして加算面像濃度 1.7のでの信号パワースペクトルを Fig.4 に示す。Al,Acの双方共、検出能に影著な差は認められない為、肺 野の濃度域ではバックを感度変化しても影響はないと思われる。又、加算画像 濃度0.6でのパワースペクトルをFig. 5 に示す。Al信号に顕著な差は無いが、Ac

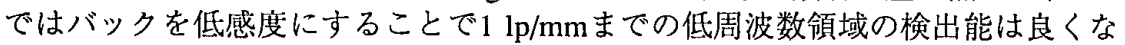
り、それ以上では差がない。縦隔の濃度域では、バックのみで画像を描出して いるため、その特性のみを反映している。

【まとめ】既存のHCシステムよりフロントには、高階調、高感度バックに おいては低階調、低感度にすることにより、鮮鋭度、低コントラスト信号の 検出能、ノイズが改善される。以上より HCシステムは、増感紙の組み合わせ はもとより、さらにインサイトフィルムの乳剤特性も今回我々の行ったシミュ レーションの様な改良をすることで画質改善の期待ができる。

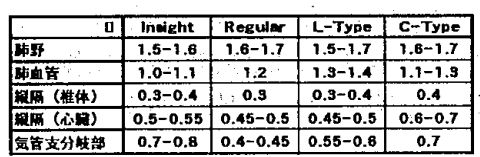

Tab. 1

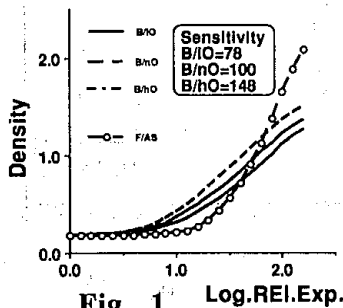

Fig. $1^{\prime}$ Log.REl.Exp

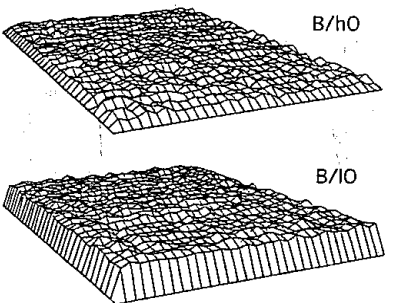

Fig.2
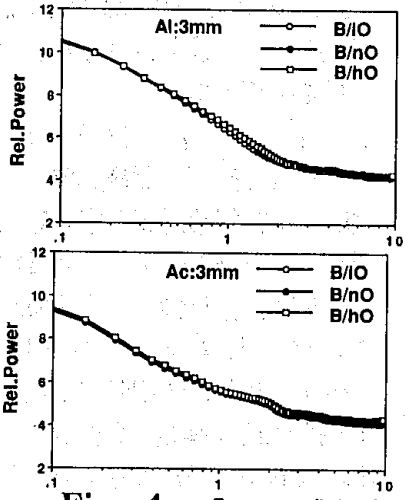

Fig. 4 Frequency $(1 \mathrm{p} / \mathrm{mm})^{10}$

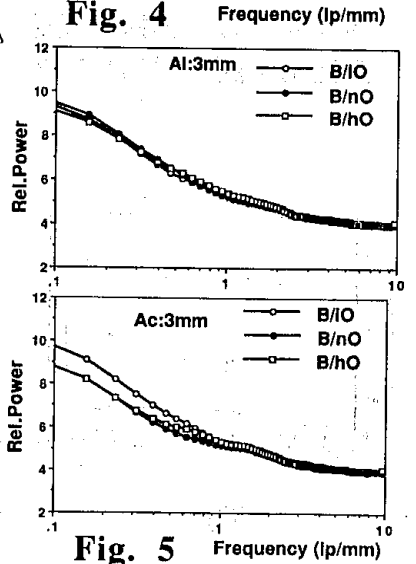

Fig. 5 Frequency $(\mathrm{p} / \mathrm{mm})$

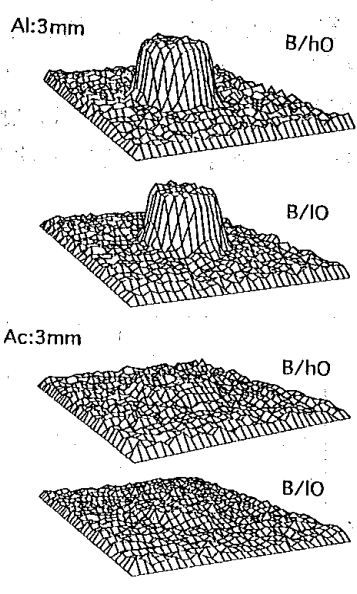

Fig. 3 